Georgetown University Law Center

Scholarship @ GEORGETOWN LAW

2001

\title{
Out of the Ordinary: Law, Power, Culture, and the Commonplace
}

Naomi Mezey

Georgetown University Law Center, mezeyn@law.georgetown.edu

This paper can be downloaded free of charge from:

https://scholarship.law.georgetown.edu/facpub/898

26 Law \& Soc. Inquiry 145-167 (2001) (reviewing Patricia Ewick \& Susan S. Silbey, The Common Place of Law: Stories From Everyday Life (1998))

This open-access article is brought to you by the Georgetown Law Library. Posted with permission of the author. Follow this and additional works at: https://scholarship.law.georgetown.edu/facpub

Part of the Law and Society Commons, Public Law and Legal Theory Commons, and the Sociology of Culture Commons 


\section{Out of the Ordinary: Law, Power, Culture, and the Commonplace}

Naomi Mezey

Patricia Ewick and Susan S. Silbey, The Common Place of Law: Stories from Everyday Life. Chicago: University of Chicago Press, 1998. Pp. 318. $\$ 42$ cloth; $\$ 16$ paper.

\section{OVERTURE}

Sometimes a work's intellectual influences reveal both its strengths and its shortcomings. This is certainly the case with Patricia Ewick and Susan Silbey's The Common Place of Law: Stories From Everyday Life, and its indebtedness to the thinking of Michel Foucault and Michel de Certeau. Taken together, Foucault and de Certeau's work suggests that investigations of law's power are most fruitful not at the level of legal institutions and the state but at the level of lived experience, where we can see how power is exercised, understood, and sometimes, resisted. This is, in essence, the narrative at the heart of The Common Place of Law, where two sociologists of law examine how law or legality (power that is at once institutional and embedded in day-to-day social practices) is recognized, resisted, and recon-

Naomi Mezey is associate professor of Law, Georgetown University Law Center. I am extremely grateful to Howard Erlanger, Heidi Li Feldman, Mark Kelman, Kay Levine, Carrie Menkel-Meadow, and Mark Tushnet for reading drafts and offering comments; to Lynn Robitaille, Rachel Taylor, and Christopher Weston for superb research assistance; to my colleagues in attendance at the Georgetown University Law Center's Summer Research Workshop for their intelligent conversation and their comments; and to Matthew Paul for everything else. 
stituted by a wide variety of ordinary people going about their lives. It is out of the most ordinary acts that law is constituted as law.

\section{Power and Resistance}

One way of thinking about Foucault's notion of power is by understanding its relationship to law. ${ }^{1}$ Alan Hunt has greatly aided this inquiry by contrasting Foucault's idea of law as the strong, centralized sovereignty of a premodern monarchy with Foucault's notion of power as the modern byproduct of discrete disciplinary mechanisms and discourses (Hunt 1992, 5-8). Foucault believed that law-understood as centralized, juridical state power-had lost its importance in modernity and had been eclipsed by power that is specific, local, fragmentary, and dispersed (Hunt 1992, 8). According to Foucault, "[w]e have been engaged for centuries in a type of society in which the juridical is increasingly incapable of coding power, of serving as its system of representation" (Foucault 1980b, 89). Hunt identifies Foucault's "expulsion" of law (and hence his lack of concern with the institutionalized power of the modern state) as the principal weakness of Foucault's work because it obscures the complex relationship between state authority and local action (Hunt 1992, 8), between what Ewick and Silbey would call "structure" and "agency."2

Certainly Foucault found that reducing power to juridical command, to law, is an inadequate explanation of its workings. "Law is neither the truth of power nor its alibi. It is an instrument of power which is ance complex and partial" (Foucault 1980a, 141). Rather, Foucault understood power as inextricable from social relations and discourses and, as such, conceived it as "power relations" that are "interwoven with other kinds of relations (production, kinship, family, sexuality) for which they play at once a conditioning and a conditioned role" (Foucault 1980a, 142). ${ }^{3}$

Foucault's thinking about power expresses an ambiguity worth noting. Sometimes he takes a descriptive approach to the pervasive fragmentation and dispersal of power; it is in this sense that he refers to "the omnipresence of power" (Foucault 1980b, 93). As a descriptive matter, power is everywhere "because it comes from everywhere" (Foucault 1980b, 93). Elsewhere,

1. For all of Foucault's theorizing, his writing on power does not really amount to a theory, thus my use of terms like "notion."

2. Duncan Kennedy has done a masterful job of putting law back into Foucault's theorizing about power in his essay on Foucault and Robert Hale (Kennedy 1993, 111-25).

3. Moreover, power only exists when it is exercised, and its exercise is always directed toward the possible actions of others. "The exercise of power is not simply a relationship between partners, individual or collective; it is a way in which certain actions modify others. Which is to say, of course, that something called Power, with or without a capital letter, which is assumed to exist universally in a concentrated or diffuse form, does not exist. Power exists only when it is put into action, even if, of course, it is integrated into a disparate field of possibilities brought to bear upon permanent structures" (Foucault 1982, 219). 
and more often, power is more distinctly disciplinary and ideological, understood as "the techniques and tactics of domination" (Foucault 1980a, 102). It is against power in this normative sense that we encounter resistance as a struggle for freedom.

For, if it is true that at the heart of power relations and as a permanent condition of their existence there is an insubordination and a certain obstinacy on the part of the principles of freedom, then there is no relationship of power without the means of escape or possible flight. Every power relationship implies, at least in potentia, a strategy of struggle. (Foucault 1982, 225)

Foucault names this struggle resistance, but cautions that it cannot be thought of as exterior to power. Resistances are inscribed in power relations "as an irreducible opposite" (Foucault 1980b, 96). Thought of in this way, resistance does not operate against power but rather in conjunction with it.

[T] here are no relations of power without resistances; the latter are the more real and effective because they are formed right at the point where relations of power are exercised; resistance to power does not have to come from elsewhere to be real, nor is it inexorably frustrated through being the compatriot of power. (Foucault 1980a, 142)

Precisely because power relations in this sense cannot exist without struggle, even when power operates by tacit consent, Foucault concludes that power is more easily located and analyzed by looking at the various forms of resistance to it (Foucault 1982, 211). But the insubordination and struggle that mark both the existence of power relations and resistance to them should not be confused with the violence of confrontation. Foucault warned against thinking of power relations as creating the dominators and the dominated (Foucault 1980b, 92), and suggested instead that we envision a "multiform production of relations of domination" (Foucault 1980a, 142). Thus, resistance is best understood not as confrontation, but as deflection, ruse, or improvised evasion.

It is Foucault's ideological view of power that is pivotal in The Common Place of Law. Arguably, his descriptive view of power as inhabiting even the microscopic details of daily life influences the framing of the project, but more notably, the analysis itself is animated by the normative pairing of power and resistance. Foucault's influential conviction that power is not a thing but a set of specific and local social relations (Foucault 1982, 217) together with his suspicion that investigations of power relations are most fruitful at the sites of resistance are central to Ewick and Silbey's project.

These same insights have also driven a small boom in studies of everyday life (e.g., Sarat and Kearns 1993; Yngvesson 1993). Theories of 
everyday life, which tend to take up where Foucault left off, are the second notable influence on The Common Place of Law, especially the bible in this field, Michel de Certeau's The Practice of Everyday Life. De Certeau relies on what he calls Foucault's "microphysics of power," which "shows how, from the wings as it were, silent technologies determine or short-circuit institutional stage directions" (de Certeau 1984, xiv). What interests de Certeau are these silent technologies, the "popular procedures" or "ways of operating" by which ordinary people "manipulate the mechanisms of discipline and conform to them only in order to evade them" (de Certeau 1984, xiv). De Certeau focuses on resistance rather than on power relations, on the tactical acts of almost imperceptible defiance. It is precisely these tactics of resistance that de Certeau makes the subject of his book; ${ }^{4}$ his aim is "to bring to light the clandestine forms taken by the dispersed, tactical, and makeshift creativity of groups or individuals already caught in the nets of "discipline" (de Certeau 1984, xiv-xv).

Taken together, Foucault's theory of power as local and social and de Certeau's ideas about popular evasions of power suggest an analytical strategy for sociolegal researchers: by examining the unexamined details of quotidian acts or popular artifacts (driving, shopping, arguing with a neighbor, a torn-up parking ticket) one can glimpse not only how power relations take shape in their social context, but also how power is resisted. This is the approach Ewick and Silbey take in The Common Place of Law.

\section{The Common Place of Law}

In 1992 Susan Silbey published a commentary on Alan Hunt's essay about Foucault entitled "Making a Place for a Cultural Analysis of Law," which reads like theoretical field notes for The Common Place of Law. Silbey saw in Hunt's essay "an invitation, and a challenge, to field researchers to provide empirical studies that . . make visible the mechanisms of accumulation and condensation that transform individual local actions into regular, repeated patterns, expectations, and institutions that in turn have the capacity to shape local techniques" (Silbey 1992, 39, 40-41).

Ewick and Silbey accept that challenge and use exhaustive empirical research to explicate what they call a constitutive theory of law, in which law is recognized as both constituting and being constituted by social relations and cultural practices. In attempting to make visible the mechanisms by which discrete individual actions become legal and institutional, and

4. De Certeau distinguishes tactics from strategies. The latter are the calculations of the powerful that operate within their own formal spaces, such as a city, a courtroom, or a university. The former are the actions of those without power. "The space of the tactic is the space of the other. Thus it must play on and with a terrain imposed on it and organized by the law of a foreign power" (de Certeau 1984, 35-37). 
vice versa, Ewick and Silbey begin making methodological sense of a cultural analysis of law. They understand culture as the bridge between local practices and institutionalized power, and they use the vocabulary and theoretical tools of cultural studies to frame the inquiry into how that span is constructed and traversed.

Just as Foucault aimed to create a history of the ways in which human beings in our culture are made subjects (Foucault 1982, 208), Ewick and Silbey engage in an analogous, though more discrete, project: to explain how in (and more important, through) our culture human beings are made as legal subjects and how the ways in which they understand themselves as legal subjects in turn affect (not surprisingly) how they and others understand the law. Ewick and Silbey look outside the formal legal institutions that have been the site of inquiry for other scholars; like Foucault, they are interested less in law than in legality, in the more dispersed and less visible workings of power and discipline. Like de Certeau, they focus on resistance and the potential revelations of the mundane, on the question of "how, where, and with what effect law is produced in and through commonplace social interactions within neighborhoods, workplaces, families, schools, community organizations, and the like. How do our social roles and statuses, our relationships, our obligations, prerogatives, and responsibilities, our identities, and our behaviors bear the imprint of law?" (p. 20). But they also complicate the relationship between law and its subjects by showing how law is as much a product of social life as it is a producer. "In short, the commonplace operation of law in daily life makes us all legal agents insofar as we actively make law, even when no formal legal agent is involved" ( $p$. 20).

A cultural analysis of law, or Ewick and Silbey's constitutive theory, suggests that law is a product of the reciprocal nature of meaning-making: people create meaning as they engage in social practices, and at the same time, the social practices (legal or quasi-legal in this case) in which people engage gain legal meaning and force as they calcify into familiar and repeated forms. In other words, we understand the law against a backdrop that is the accumulated sense others have made of the law, and each time we make sense of the law in new contexts and invoke it in new ways, we add to what "law" means. In making sense of law-or the more expansive and less formal "legality"-we make it. Constitutive theory is common law in its most literal sense: law crafted by ordinary people operating creatively under certain constraints. It is also not unlike the formation of a coral reef: living, minutely made, symbiotic. Although it generally appears in its reified form as a seemingly external object, at heart the law is the accumulation of the tiny and intimate acts of people as they go about their business and try to make sense of the world; in other words, law is the embodiment of social 
practices. ${ }^{5}$ This dynamic, popular process of making the law is what Ewick and Silbey call "legal consciousness." Making this opaque concept more concrete is the main drama of the book.

\section{MAIN ACT: A CULTURAL ANALYSIS OF LAW}

\section{Looking Out Far: A Theory of Legal Consciousness}

"How do people experience and interpret law in the context of their daily lives? How do commonplace transactions and relationships come to assume or not assume a legal character? And in what ways is legality constituted by these popular understandings, interpretations, and enactments of law?" (p. 33). These are the core questions that Ewick and Silbey pose, and in some sense their answer is, simply, legal consciousness, a concept that does much of the book's theoretical work. "In order to discover the presence and consequence of law in social relations, we must understand how legality is experienced and understood by ordinary people as they engage, avoid, or resist the law and legal meanings. This is the study of legal consciousness" (p. 35). Indeed, their approach to the concept of legal consciousness is the book's central achievement and ultimately is a more valuable contribution to a cultural analysis of law than the specific forms they claim for it after the data have settled. ${ }^{6}$ Their methodical elaboration of legal consciousness as cultural practice merits attention.

5. W. H. Auden attributed this view to legal scholars as early as 1939 . His wonderful poem "Law Like Love" is reprinted in the front of The Common Place of Law, and one stanza in particular makes this point:

Yet law-abiding scholars write:

Law is neither wrong nor right,

Law is only crime

Punished by place and by times,

Law is the clothes men wear

Anytime, anywhere,

Law is Good-morning and Good-night. (Auden 1966, 154)

It is not accidental that Auden was writing during the heyday of legal realism, which initiated a call for a new kind of legal thinking that is still being answered today and to which this book could be said to be responding. Karl Llewellyn himself declared that one of the innovations of the realist movement was its departure from traditional legal subject matter: realists urged attention to "the life that swirls around things legal" (Llewellyn 1931, 1222) and advocated a study of law that included the study of the community which a particular law affects, concluding that law has little meaning once it is divorced from those who find it meaningful, or from that which has traditionally been thought of as not-law (Llewellyn 1931, 1248-50).

6. Ewick and Silbey are not the first to talk about "legal consciousness" as such, and they note many other studies of American legal consciousness (p. 273, n.9). However, while some others use the term to mean something quite similar (e.g., Merry 1990), Ewick and Silbey do a particularly good job of giving the concept theoretical specificity. Michael McCann and Tracey March provide a nuanced discussion of a number of formulations of legal consciousness, including that of Ewick and Silbey (McCann and March 1995, 211-16). 
Ewick and Silbey distinguish legal consciousness from other conceptualizations of consciousness that have been used in legal and political theory. They are most eager to distinguish it from two familiar extremes: the neartotal free will of the individual in liberal theory and the stark determinism of structuralist thinking. Their point is that legal consciousness, like virtually any kind of consciousness, falls somewhere in between. It does not give as much power to the "reason and desire" of the individual actor as liberalism does (p. 36), but neither does it cede all control to the "social and economic structure" in which people act (p. 37). As Ewick and Silbey conceive it, legal consciousness is neither attitude nor epiphenomenon, but cultural practice (pp. 35-38).

Legal consciousness as cultural practice attempts to integrate human agency and structural constraint by showing how individual understandings and social interactions aggregate to partly shape institutions (agency) while institutions and larger social structures provide the foundations for and constraints on individual understanding and social interaction.

A notion of consciousness as determined solely by forces beyond the individual renders the thinking, knowing subject absent. Within this perspective there is no way to account for the rich interpretive work, the ideological penetrations, and the inventive strategies related to us by the persons with whom we spoke. On the other hand, a notion of legal consciousness that focuses solely on individual ideas (as attitudes or opinions) fails to connect people's accounts with their lived experiences, including the constraints operating within those particular locations. It fails to provide a coherent report of the finite and limited range of options available to people in either fashioning their interpretations or choosing their behaviors. (P. 38)

Ewick and Silbey refuse to forgo either the agency that we all believe we have or the countless constraints on that agency that we often fail to acknowledge. In other words, while both models-those of free-will and determinism-are necessary, the authors argue that neither one is sufficient to explain how people make and make sense of the law.

To describe the reciprocity between individual action and larger social structures such as law, Ewick and Silbey rely on cultural theory, that quirky, ill-defined hash of insights from different disciplines. First and foremost, cultural theory suggests a social constructivist approach, ${ }^{7}$ which seeks to show how the world as we know it is not found, but is continuously in the making by the archeological accretion of our individual and collective ascriptions of

7. Much has been written about social constructivism, which is often contrasted with essentialism or immutability (generally in the form of biology or economics), as a means of explaining the existence and durability of social practices and identities. Some of the scholarship on sexual identity provides a particularly lucid example of the debate (see Foucault 1980b; Halley 1994). 
meaning to the things, events, and places we inhabit. Ewick and Silbey use the vocabulary of William Sewell (1992) to describe this effect, attributing the ongoing reproduction of social life to the dual operation of "schemas," the "cultural codes, vocabularies of motive, logics, hierarchies of value, and conventions" (p. 40) which are the tools with which we build the world, and "resources," such as "knowledge, capital, property" (p. 41), which influence how much power we have in wielding the tools. "Having only virtual existence, schemas must find articulation in the resources which instantiate them" (p. 41). And schemas in turn give resources their cultural salience.

We can also attribute to cultural theory the elaboration of the notion of reciprocity, or constitutive theory itself: not only are society and its institutions collectively constructed by "us," but who we are and how we understand ourselves is always compromised by the social world we make. In the dance of mutual constructedness, the local and minute social practices that contribute to the making and remaking of the larger social structures (like law) are in turn informed and constrained by the meanings and opportunities available to them by those very structures. It is here that we regain "consciousness," the term Ewick and Silbey use to describe our participation in giving meaning and form to the social world. "Within this framework, consciousness is understood to be part of a reciprocal process in which the meanings given by individuals to their world become patterned, stabilized, and objectified. These meanings, once institutionalized, become part of the material and discursive systems that limit and constrain future meaningmaking" (p. 39).

Ewick and Silbey address two important and related points with respect to the constructedness of the social world. First, the language we use to describe the world-"as immutable, inevitable, or natural" (p. 41)-masks its malleability and denies the fact that only through language and culture have we given it those attributes. ${ }^{8}$ We invent the world to look and feel as if it could not have been invented. As the poet Richard Wilbur has written, "It is a puzzle which, as puzzles do, dreams that there is no puzzle" (1988, 39). Second, and this is perhaps the most easily misunderstood aspect of the constructivist argument, the social world is no less real and no more subject to individual whim simply by virtue of being the product of our collective understanding. To use the authors' own example, we now attribute the widespread belief in witches during the Renaissance to a mistaken historical consensus (pp. 42-43). That is, we appreciate that the "reality" of witches was the product of a collective misunderstanding. However, if you lived at

8. For example, the discourses of race, gender, and sexual orientation orbit around linguistic and cultural categories (such as black-white, male-female, homosexual-heterosexual) that through discourse take on the appearance of biological fact. Thus, differences in race, gender, and sexual orientation come to seem inevitable because those categories tend to be defined by the most visible and enduring indicia of difference (skin color, genitalia) despite the fact that equation of skin color with race and genitalia with gender are cultural "choices." 
that time, vehement objection to the reigning belief in witches as mere social construction would not have kept you from being burned. 9 The more stabilized and calcified the belief by consensus and duration, the more it registers as fact (p. 43).

So where does the law fit into this theorizing? Law in The Common Place of Law is paradoxical: it is everywhere and nowhere. Ewick and Silbey interviewed hundreds of people for their book, many of whom faced not-solegal institutions and actors with concepts no more legal than the notions of contestation or authority. One wonders, then, what is legal about the consciousness they describe. The degree to which law gets lost may be attributable to the influence of Foucault. By looking for the exercise of power in the mundane extremities of everyday life, by locating legality wherever vaguely legal concepts are embedded in social practices, Ewick and Silbey radically reconceptualize what the law is. Losing law in society is partly their point ( $p$. 35). But it also means losing any meaningful distinction between Rita Michaels's experience in divorce court (p. 60) and Charles Reed's protest to the school board about a teacher's transfer (pp. 115-16), or between being arrested and contesting the water bill. To the extent that they have authoritative power in people's daily lives, all the institutions, rules, and conventions that people defer to or defy are equally part of legality. Legality, then, is at least as pervasive as Foucault's power; it is "all over" (Sarat 1990). "Legality is not inserted into situations; rather, through repeated invocations of the law and legal concepts and terminology, as well as through imaginative and unusual associations between legality and other social structures, legality is constituted through everyday actions and practices" ( $p$. 43). In this sense, the law is everywhere, so much so that it is nowhere.

To bring us full circle, legal consciousness is the name Ewick and Silbey give to "participation in the process of constructing legality" (p. 45). It describes an "emergent, complex, and moving" (p. 46) process by which

"each person's participation sustains legality as an organizing structure of social relations. Every time a person interprets some event in terms of legal concepts or terminology-whether to applaud or to criticize,

9. This is equally true for modern realities. We may insist that race, gender, and sexual orientation are socially constructed identities (meaning, for example, that they are simply-or not so simply - the product of a historically contingent consensus about what constellations of characteristics and activities are seen as socially or politically salient), but that does not mean that any one of us can opt out of the construction and choose to have no race, no gender, or no sexual orientation. This is not to say that people can't challenge the prevailing meaning and seeming rigidity of such categories; they do, but not easily, and only with the most incremental effects on the categories themselves. It appears that only with extraordinary effort, pain, and infrequent success can any of us move between races, genders, or sexual orientations once conferred; and even then, it is generally still within the established matrix of what race, gender, and sexual orientation mean. Nor does social constructivism make racism, sexism, or homophobia any less real or their consequences any less concrete. 
whether to appropriate or to resist-legality is produced. The production may include innovations as well as faithful replication" (p. 45).

Thus, each of us participates not only in reproducing the law, but also in minutely remaking it.

In spite of the somewhat paradoxical invocation of law in their formulation of legal consciousness, Ewick and Silbey's theoretical description of the reciprocal processes by which the law, the self, and social practice are mutually constructed is nonetheless a tremendous contribution to a cultural study of law. At the level of theory, the ambiguity of legality is not so problematic. They artfully pull together the literature of sociology and cultural studies to articulate how the law is intimately bound up in the constructions of self and society, and vice versa. They show, for example, how law's claims to autonomy and transcendence are simply one form that the social construction of law takes. More important still, by demonstrating what a cultural analysis of law might mean at a theoretical level, they facilitate the work of legal and sociolegal scholars who want to investigate the relationship between legal and cultural production in the context of particularized legal questions.

\section{Looking in Deep: A Practice of Legal Consciousness}

Every theory is skeletal and needs facts and examples to flesh it out. The bulk of The Common Place of Law is dedicated to that task. Based on indepth interviews with over 400 people, Ewick and Silbey structure their book around the three types of legal consciousness they identify: "before the law" describes the law as grand, public regarding, and neutral; "with the law" sees the law as an arena of strategy and self-interest; and "against the law" considers how people respond to the oppressive power of the law. While each of these are given particularity along theoretical and factual dimensions using details from their painstaking and fascinating research, ${ }^{10}$ the result feels less novel and less convincing than one would expect from either the authors or the project. In the end, the factual guts of the book, however lucid and engaging, don't deliver on the theoretical promise of the enterprise.

10. Ewick and Silbey and their team of interviewers talked at length with roughly 430 residents from four counties in New Jersey (p. 252). The sample was chosen so as to approximate the demographic composition of the state (p. 256). Of those interviews, 141 were transcribed and analyzed qualitatively using 40 thematic keywords (pp. 253-54). The most frequent themes formed the basis for their conceptualization of legality: "As we read the transcripts, the repeated allusions to God, to bureaucracy, to games, to play, and to tricks and subterfuges emerged as prominent themes. .. . These themes were echoed in so many stories, across such varied persons and situations, that we became convinced that they are common features of legality within the lives and experiences of ordinary Americans" (pp. 255-56). 
The three forms of legal consciousness that Ewick and Silbey chronicle, while described with occasionally fresh and delightful examples culled from their interviews, suffer from two problems. The first is that the concepts are not new. Perhaps Ewick and Silbey conceptualized the forms of legal consciousness with a lay audience in mind, but the categories they describe approximate long-familiar legal constructs. For example, the authors describe "before the law" as "law's own story" (p. 83), in which law is majestic, neutral, and authoritative.

In this form of consciousness, the law is described as a formally ordered, rational, and hierarchical system of known rules and procedures. Respondents conceive of legality as something relatively fixed and impervious to individual action. In a sense, respondents tell the law's story of its own awesome grandeur, something that transcends by its history and processes the persons and conflicts of the moment. It is often regarded as somewhere else, a place very different from everyday. Objective rather than subjective, the law is defined by its impartiality. (P. 47)

Furthermore, in this form, the law "achieves its impartiality and objectivity through a deliberate indifference to the particularities of biography or personality. Thus it is understood that as they stand before the law, all persons appear and are treated the same" (p. 76). This type of legal consciousness sounds an awful lot like formalism, albeit the somewhat clichéd and generalized formalism in which law denies its own constructedness and claims for itself the orderliness, rationality, and objectivity of science. It also partakes of the formalist belief in the neutrality of rules. ${ }^{11}$

Likewise, "with the law" describes a form of legal consciousness in which the law is engaged as a game. The rules differ from those of everyday life, but the boundary between the two is amorphous. "It is an arena of competitive tactical maneuvering where the pursuit of self-interest is expected and the skillful and resourceful can make strategic gains" (p. 48). This vision and invocation of law acknowledge that people have unequal access to the game and unequal skills once engaged (p. 132), but that those disparities don't always determine who plays and who wins because sometimes the means are as important as the ends (p. 133). Law may be deployed, or played, for "expressive or communicative purposes" (p. 133), or even for pleasure (p. 134), and not just to secure a desired result. Again, this sounds oddly familiar. It was over half a century ago that the legal realists sought to expose the self-interest, subjectivity, and irrationality at work in

11. Both Robert Gordon (1994) and Thomas Grey (1983) have discussed the many and shifting definitions of formalism. Gordon notes that formalism "has proved maddeningly elusive" partly because it tends to be viewed through the critical and interested lens of the realists $(1994,155)$ rather than by its own advocates, to the extent that they exist as such. 
law and attempted to show how will, wealth and historical fortuity masqueraded as reason and right (Fisher, Horwitz, and Reed 1993, 49-75). Roscoe Pound, for instance, noted in his famous exchange with Karl Llewellyn that the new generation of realists departed from nineteenth-century legal thought by emphasizing "the uncertainties, the lack of uniformity, and the influence of personal and subjective factors in particular cases" (reprinted in Fisher, Horwitz, and Reed 1993, 64).

Finally, "against the law" conjures a form of legal consciousness in which legality offers no other alternatives except submission or subversiveness. "People exploit the interstices of conventional social practices to forge moments of respite from the power of law. Foot-dragging, omissions, ploys, small deceits, humor, and making scenes are typical forms of resistance for those up against the law" (p. 48). This form of legal consciousness is found among those aware of their own powerlessness and is illustrated by the tactics they use to protect themselves or pursue their own ends. These strategic acts of the ordinarily powerless are precisely what Foucault and de Certeau meant by resistance, and they are the wry punch line of a book whose explicit assumption is that even the least powerful and sophisticated among us contribute to the "common" understanding of-and hence, official constraints on-what law is. It is in the extensive discussion of resistance and the tactics of the powerless that the book's debts to Foucault and de Certeau stand out.

Ewick and Silbey suggest that resistance has three defining features: an awareness of being the less powerful in a relationship of power, the existence of a situation that can be turned to one's advantage, and a justice claim (p. 183). Theirs is the resistance that, in Foucault's normative ordering, is power's conjoined twin. The forms it takes are those chronicled by de Certeau: the ruse and tactical creativity in otherwise unnoteworthy acts of everyday life. Like the other forms of legal consciousness that the authors name, "against the law" has its antecedents in legal theory. While not so readily evident in conventional legal thought as its compatriots, "against the law" nonetheless borrows heavily from various critical legal theories, including critical legal studies, critical race theory, and feminist legal scholarship, which for all their differences share, at minimum, a view of legal doctrine as inherently contradictory, a sense of the political possibilities that arise from those contradictions, and a critique of liberal ideology as legitimizing the unequal distribution of wealth, power, and privilege (e.g., Kelman 1987; Kairys 1990).12 Moreover, feminist and critical race scholars

12. Interestingly, with slight modifications in the vocabulary, these could also be said to be common views of the legal realists. As others have noted, there are many ways in which critical legal scholarship is a "continuation of an abandoned Realist project" with political radicalism taking over for reformist fervor (Note 1982, 1669; Tushnet 1980, 1385-86). The realist legacy within classic law and society work provides still another model of thinking "against the law." 
have contributed to such visions of the law in ways that invoke the importance of the commonplace by resurrecting the lived experiences of women and people of color to show not only the forms that domination has taken but also the ways in which domination has been resisted, deflected, or appropriated (e.g., West 1987; Austin 1988). Ewick and Silbey bring animating and provocative examples to these familiar categories, and they certainly seem to recognize that some forms of legal consciousness they found in their lay respondents line up with schools of thought within legal studies (p. 164), but one is left wanting them to make the connection explicit and to use it to speculate on the nature of the relationship and modes of interaction between commonplace legal consciousness and elite legal theorizing.

The second and more troubling problem with the book is one of factual and theoretical fit; the impressive empirical work and the elegant theorizing do not consistently come together. The undeniably interesting data Ewick and Silbey have amassed occasionally seem strained and unconvincing when they are asked to support the theoretical structure. Ewick and Silbey frame their project ambitiously-to begin filling in that vast blank space between theoretical descriptions of the world and the particular social practices and discourses that justify and animate the theory. Indeed, they realize that this sort of gap filling is their primary task (p. 76) (it might be said to be one of the central tasks of all cultural analysis), and they do make important progress. As I have indicated, they detail how the respondents' reactions to conflict, authority, and unfairness in quotidian contexts are informed by legal concepts and in turn inform varieties of legal consciousness. They also show how legal consciousness is interpolated back into everyday life. Millie Simpson is on the one hand deferential and mystified when she appears in court for driving an uninsured car, an encounter in which she stands submissively before the law; on the other, she is tactical and resistant in the face of judgment, conspiratorially recounting how she managed to fulfill her legal obligation to perform community service with volunteer work for her church that she does anyway (pp. 4-12).

But the results are not always successful. Too frequently details and examples, often conveyed by narrative quotation, don't sufficiently support the kinds of legal consciousness they are meant to illustrate, ${ }^{13}$ making the authors' analysis seem forced. In these instances, theory overtakes the particularity of fact. For example, in their discussion of "before the law," Ewick and Silbey describe how people's words and actions contribute to the

13. Each form of legal consciousness is further analyzed in terms of four categories or variables that, the authors argue, "constitute the most basic and significant variables for describing not only legality, but any instance of social action." Those variables are normativity, constraint, capacity, and time and space (p. 82). Ewick and Silbey don't offer much ammunition for their bold argument that these are the most basic categories for understanding social action, nor do the categories add significantly to the analysis of the data. 
reification of the law. This is an important point; based on their analyticai model, we would want to know how-that is, by what social practices or discourses-the law is rendered external, coherent and thing-like. In showing us how, Ewick and Silbey are only partly convincing. They conclude that reification occurs when people sever their distaste for the unjust acts of particular legal actors from their general respect for "the courts," "the police," or "the system" (p. 79). They further contend that reification is effectuated by thinking about legality in four specific ways: as something that should be reserved for issues of public concern rather than self-interest, as being located in rules and regulations outside individual control, as powerful, and as timeless. The authors identify the last of these, the timelessness of law, as "perhaps the most salient feature of reified law" (p. 95), yet their discussion of law's timelessness is among the most uneven of the book.

Here, Ewick and Silbey attest that legality is understood as timeless by their respondents when it is described as outside time and spatialized, embodied in places and texts. The authors then explain, rather briefly, how modernity and capitalism have disciplined, rationalized, and spatialized time (p. 96); how the spaces law occupies are removed from daily life; and how the time spent there is just that-spent, commodified, formal. This makes a certain amount of intuitive sense, but it is extremely hard to tell from the data they present how or why it is true. We are offered 14 quotes from various respondents, 13 of which simply attest to having to wait a long time at the Department of Motor Vehicles, at traffic court, at the police station, or for a court appearance (pp. 97-98). A representative example: "When I was going to traffic court, one time I went there the lines were just horrendous. ... It's a pain" (p. 98). While Ewick and Silbey believe that these excerpts show how "law's time is experienced as a disruption of the repetitive cycles of everyday life" (p. 98) and therefore contributes to its reification, the quotations offer little evidence that these waits are experienced as qualitatively different from the long waits entailed in opening a bank account, seeing a movie on opening night, registering for classes-aspects of life that are both nonlegal and ordinary and that we don't think of as reified within the legal domain. ${ }^{14}$ In other words, in this instance we are given no data that really help to illuminate either how the reification takes place, how it is that historically or culturally people come to see law as timeless and to see themselves "before the law," or (assuming reification does take place in this way) why it takes place with respect to law but not banking or movie

14. Each of these activities might be reified within a different domain, say within the economy, entertainment, or education. And certainly each activity has legal aspects to it. Peter Gabel's elaborated encounter with the bank teller is a nice corrective to my debatable assumption that opening a bank account is a nonlegal experience (Gabel 1984). But I still think it is safe to say that in the context of everyday life these activities are generally not experienced as legal. 
going. Instead we are left with very general words and phrases being harnessed as support for theories that demand greater particularity.

Ewick and Silbey are more successful at coupling theory and data in their discussion of the reification of law through the use of text. They take up how the "spatialization of legal relationships through textualization contributes to the experience of a reified-thing-like-legality" (p. 99). After discussing the myriad and obvious ways in which law privileges the written text, Ewick and Silbey make the more nuanced point that law's written order displaces both author and audience; they invoke de Certeau's observation that entering legality, even by so simple a means as writing a letter to an agency, entails both the pleasure and sacrifice of being "inscribed in a symbolic order that has neither owner nor author" (p. 102; de Certeau 1984, 140). Ironically enough, becoming legible to the law confers recognition and identity even in the face of law's facelessness. "Papers, documents, identity cards, and permits represent material evidence of social existence. Often to receive one's papers, whether a green card or a handicapped-parking permit, is to become someone different, to be officially recognized, and thus to enter the social script" (p. 102). Here, the respondents substantively attest to the point. The most touching is a statement by Aida Marks:

I really had no identification until I got in touch with the commission of the blind and then they gave me my, what do you call that transportation card for the buses and the trains? They gave me an ID card, ... I never had really no identification, there's a lot of women that don't have identification if you're a housewife or something, you don't have anything that says Aida Marks that says that, I didn't have anything. (P. 103)

Of course, the power and authority of the written text can erase and disfigure identity as well as confer it, and Ewick and Silbey effectively note the ways in which respondents felt that they had not been recognized or remembered because their documentation had been lost or no one read their papers, or the ways in which they were subjected to bureaucratic errors that implicated what others thought of them (pp. 103-5).

\section{Looking for the Middle Distance: Bridging Theory and Practice}

When the book works, it works extremely well. It is moving to hear the voices of the people Ewick and Silbey spoke with and exciting to see their statements reinforce an interesting theoretical point. However, persistent gaps exist in the power of the data. Certainly the stories people tell about the law explain how they experience it, and it even makes sense to 
generalize from those accounts and say something about how Americans (or at least those who live in New Jersey) understand law. ${ }^{15}$ But the stories themselves don't always adequately illustrate the larger theoretical claims of the book-how individual experiences of the law help construct the law more broadly by contributing to and incrementally changing its meaning. It seems plausible, for example, that law's distinctive and pervasive emphasis on textuality contributes to a reified view of law and that as people invoke the power of legal texts, they participate in constructing this vision of legality. But how exactly? This is the hardest of questions to ask of this kind of work. And perhaps it is not entirely answerable. But I suspect that one reason that the unanswered question lingers here and leaves a little disappointment is because the book aspires to unpack, theoretically and empirically, some of the mechanisms by which law mutually engages the most intimate and mundane social practices.

The fact of the matter is we still don't know much about how the individual shells of experience and perception become the coral reef of culture, and it may be asking too much of this book to tell us more than it does. But what is missing from this book is also precisely what is missing from this field: the research that will clarify how individual meanings and practices become patterned and objectified, the process by which individual acts become part of the institutional architecture. The importance of The Common Place of Law is that it points in the right direction and even gets us part way there. In the context of speaking to a narrower issue, Ewick and Silbey pose the question that I think is fundamental to their larger project and to cultural inquiry more broadly. "How do innumerable discrete, often disjointed and sometimes contradictory, transactions cumulate to produce the experience of singularity and coherence? In other words, through what social practices and discursive forms is the law apprehended as an object: thinglike and inert, powerful and permanent, fixed and remote?" (p. 76). The goals and theoretical approach of the book are well suited to shed light on such a question; however, the book's reach may be compromised by the empirical method Ewick and Silbey employ. While it is clear from the methodological appendix (p. 251) that their study was carefully designed with prior research in mind, the interviewers trained and supervised, and the data scrupulously compiled, the research nonetheless purposefully relies entirely on narratives. Thus the authors have either individual voices or broad generalizations based on an aggregation of the anecdotal; the combination is not consistently convincing. This creates a limitation evident throughout the book: Ewick and Silbey are exceptional at bringing both the concrete details and the framing theories to life, but I suspect that the most powerful

15. This is not a gratuitous swipe at New Jersey. Rather, our ability to generalize based on the findings in the book is limited by the scope of the study. See note 10 . It was not the authors' task or intention to tailor their research to the entire United States. 
explanations for the complex relationship between the quotidian acts and accounts of ordinary people, the common understandings of law, and the construction of legal subjects lie somewhere in between. The Common Place of Law builds on the strengths and replicates the weaknesses of the traditions to which it is most indebted. Foucault and de Certeau are both poetic theorists who point to local sites and concrete practices in passing illustration of their theories. Ewick and Silbey amply fill in the local details and color, but like Foucault and de Certeau, they don't cover the terrain of the middle distance.

What is missing are the midlevel theories and cultural practices that could bridge the specificity and abstraction and provide an account of how a cultural, constitutive theory of law actually works. These intermediate cultural practices are those in which individual conceptions of the law are popularized and popular conceptions of the law are "written" onto the individual. "There is no law that is not inscribed on bodies. . . From birth to mourning after death, law 'takes hold of bodies in order to make them into text. Through all sorts of initiations (in rituals, at school, etc.), it transforms them into tables of the law, into living tableaux of rules and customs, into actors in the drama organized by a social order" (de Certeau 1984, 139). It is the forms of initiation, the cultural practices that mediate between the law and bodies, which we must study in order to understand how the nomos and the narrative come together. To the extent cultural practices make law, it is important to know not only how this process takes place but also the different forms it takes. For instance, the formal legal ratification of social convention and cognitive psychology evident in negligence law (Feldman forthcoming) is quite different from the way social rules and conventions displace formal law among cattle ranchers in Shasta County (Ellickson 1986).

If cultural practices mediate between law and individual bodies, then we need an account of how cultural practice works-the mechanisms of transmission and inscription. Ewick and Silbey might be right that the primary mechanisms of social action and cultural practice are stories, individual narratives that circulate and become the basis of collective action ( $p$. 220). Ewick and Silbey relate instances of individual private transmission: Sophia Silva tells a young mother to stand her ground at Sears until she gets a replacement vacuum cleaner (p. 218); Bess Sherman discusses with her friends and neighbors how to get help with SSI benefits (pp. 169-70). But how and when does the circulation of narrative come to form a pattern that is more broadly recognizable as cultural practice? What are the mechanisms of mass public transmission? These are the questions best answered by midlevel theories. One example of such a midlevel theory might be anthropologist Dan Sperber's epidemiology of cultural representation which seeks to account for the contagion of ideas (1996). Even without a full-fledged 
theory of cultural transmission, we might look to specific sites of mass initiation and inscription. I am not thinking here of those places where law inscribes bodies directly (the courtroom, the welfare office, the prison) but indirectly, in the common places of law: the news, television shows, movies, novels, comics, high school civics courses. And what is needed is an empirical method suited to these sites and their various methods of mediation, one that focuses on the middle distance.

\section{FINALE: LAW AND SOCIETY CONFRONTS ITSELF}

Ewick and Silbey, like all good dramatists, also include a secondary drama, a play within a play that addresses, as it were, the art of theater. This secondary narrative is embedded in the conceptualization and realization of the book, and it tells a self-reflective story of long-brewing methodological and theoretical conflicts within law and society scholarship. In this little play, the empiricists and the theorists meet in the sylvan forest, and much methodological mayhem ensues only to be happily, if provisionally, resolved.

One of the most intriguing aspects of The Common Place of Law is the way it implicitly tackles an internal debate within the law and society movement about what it means to "do" law and society scholarship. To call it a debate may both understate and oversimplify it. ${ }^{16}$ At the very least a deep divergence of approach exists between empiricists who come out of the social sciences and those who have variously been called interpretive, critical, or theoretical, who hail from the more methodologically insecure disciplines (for the sake of simplicity rather than clarity I will call them theorists). ${ }^{17}$ In some sense it is also a generational conflict between the practices of the founders and the impertinence of their heirs.

Social science has been a fixture within law and society research since its inception. In fact, many would say that social science is not just a fixture but is (and should be) foundational to the law and society project (Cotterrell 1994, xi-xii; Friedman 1986, 766-67). This should not be surprising for a movement that grew out of the sociological insights and reformist impulses of legal realism (Garth and Sterling 1998, 409; Sarat and Silbey 1988,

16. Trubek and Esser contend that the attempt at synthesis between the different approaches within law and society is "a manifestation of a crisis," a crisis of self-doubt occasioned by its maturation as a movement $(1989,5)$. On the other hand, it may be overstating it to call it a debate; it may just be a tension, and even a productive tension occasioned by interdisciplinary efforts (Levine 1990a; Sarat et al. 1998, 2).

17. I want to be clear that I am not drawing a distinction between social scientists and lawyers within law and society, a topic that has been well canvassed (e.g., Levine 1990a, 9 and n.5), but between empiricists and theorists. 
104-12; Trubek and Esser 1989, 8-10) ${ }^{18}$ and that grew up during a time of high prestige for the social sciences (Simon 1999, 145). Nor is it surprising for a movement that, in some sense, has been premised on the conviction that law is a social phenomenon. Friedman articulates the challenge of the empiricist approach as applying an objective method of study to a subject that is admittedly socially contingent. "The law and society movement sits on a rather narrow ledge. It uses scientific method; its theories are, in principle, scientific theories; but what it studies is a loose, wriggling, changing subject matter, shot through and through with normative ideas. It is a science (or would-be science) about something thoroughly nonscientific" (Friedman 1986, 766).

To be fair, the embrace of scientism within law and society may have never been entirely unproblematic, particularly in a movement inhabited by thinkers trained in a wide variety of disciplines. But if a consensus once existed that law and society as a movement was about the partnership of law and social science, that consensus has long since dissolved. As Jonathan Simon points out, we live in an era in which "the social and its sciences have themselves become problematized" $(1999,177)$. Moreover, the 1980s and 1990s saw the ascendant influence of critical and cultural theory within many of the disciplines from which law and society scholars came, bringing an influx of interpretive types, people who brought not only a more theoretical inclination and less empirical training, but also an epistemological critique of the empirical method and its claim to objective standards and verifiable truths of social behavior (e.g., Lyotard 1989). These theoretically inclined scholars cautioned that it is not just the subject matter of law and society research that wriggles and changes, but that the research methods themselves are subject to the same illusions of stability.

I am not suggesting that theory was absent from the early days of the law and society movement; indeed, the seemingly undisputed forefathers of the law and society movement, Marx, Weber, and Durkheim (e.g., Friedman 1986, 766; Tushnet 1998, 580; Munger 1998, 26), were fundamentally theoretical. My contention is rather that the slightly later influence of the poststructuralists deepened the tensions between empiricism and theory within law and society. Nor is it just from the humanities that this critique emerges, ${ }^{19}$ but within the social sciences there is a decreasing "commitment to common standards of objectivity or aspiration toward epistemological unity" (Simon 1999, 147). The theorists, influenced by Foucault and de

18. I use and subscribe to this particular origin myth, but I recognize there are others (Munger 1998, 25-26). In recognizing the influence of legal realism on law and society, I am not suggesting that it was mainly a movement of legal scholars. David Trubek and Felice Levine have already debated this point (Trubek 1990; Levine 1990b).

19. I am not aligning the theoretical emphasis with any set of disciplines. The most interesting theory comes as often from social sciences like sociology and anthropology as it does from the humanities. 
Certeau among others, advocate an investigation of law that is attentive to the ways in which it is implicated in the production of knowledge and power, identity and desire. Although they work within law and society, ${ }^{20}$ these thinkers are arguably truer to the critical legal studies tradition, bringing the insights of neo-Marxism, semantics, and poststructuralism to bear on legal studies by directing their attention to the ideological, rhetorical, and discursive nature of law (Trubek and Esser 1989, 19-34). Interestingly, Friedman's characterization of the tensions between scholars inside and outside law and society sounds more like the contentious trends within law and society:

The law and society people [read empiricists], on the whole, tend to emphasize behavior (and attitudes as they affect or reflect behavior). Legal scholars [read theorists] find this emphasis uncomfortable, even threatening. To them, law is norms, or language, or ideology, or thetoric, or "consciousness," or discourse-anything but behavior. . . . Of course, the emphasis on behavior, like its opposite, can be carried to extremes. The students of behavior and the scholars of formal norms do make feeble or gingerly gestures of accommodation toward each other. This bridges the gap only slightly. (Friedman 1986, 774-75) ${ }^{21}$

The distinctions between theory and empiricism are of course not this neat. Law and society has evolved and will continue to evolve along with those who claim it as their field. But dramatizing the conflict may help to illuminate the aspirations of those who most feel the methodological tensions within law and society. Ewick and Silbey stand at the intersection of these contrary impulses within the movement and have in The Common Place of Law aspired to an integration of the theoretical and empirical traditions with a method that is "highly empirical, although decidedly post-empiricist" (McCann and March 1995, 211). They belong to a group of law and society scholars who question the instrumentalism and "universal scientism" associated with law and society work and who have sought to formulate a "critical empiricism" within the movement (Trubek and Esser 1989, 13-19).

It should be noted that Silbey has long been exploring the question of how to honestly reconcile a critical, or theoretical, approach to sociolegal studies with empirical methods (Silbey and Sarat 1987; Sarat and Silbey

20. The boundaries of intellectual movements are always shifting, so I don't want to make too much of what it means to work "within" one. For my purposes I simply mean that they have enough interest or allegiance to participate in conferences or otherwise engage in scholarly debate with those who are clearly members. In this regard, despite what I assume to be a mutual ambivalence between critical legal scholars and law and society adherents, the two groups overlap somewhat.

21. If it is not clear from the text, Friedman is using the term "legal scholars" pejoratively. 
1988; Silbey 1989). In her essay, "A Sociological Interpretation of the Relationship Between Law and Society," Silbey asserts that while sociologists have been critical in their study of law, their criticism has not adequately reached their own roles and methods.

Sociological studies of law have traditionally been pursued outside of the mainstream of legal discourse, participating at a remove while offering an alternative epistemology and jurisprudence. In this, it has been a critical enterprise, its focus decentering, concerned not with what the law is-the concern of legal elites-but with what the law does-a concern of users and receivers of law. Although this tradition encompasses a vision of a socially constructed reality, it pays less attention to its own role in constructing that reality, and in particular to the role of social scientists in creating legality. (Silbey 1989, 21)

Silbey's first substantive criticism of the effects of empirical studies is that they produce "a discourse of universality in which there are not communities but a society, in which there are not laws but the law" $(1989,22)$.

Eager to further formulate and apply a critical empiricism, Ewick and Silbey bring to their book an acknowledged debt to law and society research as well as a reconceptualization of it. They argue that while law and society research "fractures the imagined coherence of law, it rarely challenges the boundary that presumably encompasses it" such that "it is often implicitly assumed that the law is still recognizably, and usefully, distinguishable from that which is not law" (p. 19). Their investigation of legality is aimed precisely at that boundary, where social acts and imaginings take shape as law. In looking to commonplace events and actions, Ewick and Silbey reconceptualize law "as social action" (p. 35). They contend that thought of in this way, as "law in society," the old law and society question becomes incoherent because it "presupposes the very thing that is now understood to be problematic: how it is that the law emerges out of, or is constituted within, local, concrete, and historically specific situations" (p. 35).

One irony of their critical empiricism is that the strengths of the approach bring their own weaknesses. For example, as I noted above, once law is reconceptualized as all forms of power and authority, legal consciousness is no longer meaningfully legal. In addition, while the use of narrative data is not consistently persuasive, it is precisely their very strategic use of narrative that makes The Common Place of Law a brilliant integration of the theoretical and empirical impulses within law and society. Quite apart from how useful their data prove to be, the use of narrative as the methodological basis of their empirical study can be seen as a welcome and mostly successful attempt to use a qualitative method that simultaneously questions the authority of scientific description in traditional empiricism. 
The Common Place of Law is intelligent, passionate and ambitious. In spite of the ways in which it accomplishes less that it aspires to, it succeeds in forcing anyone who cares even remotely about the relationship between law and culture to think more carefully about what that relationship looks like-its premises, its forms of engagement, and its consequences. And that is the highest compliment of all.

\section{REFERENCES}

Auden, W. H. 1966. Collected Shorter Poems 1927-1957. New York: Random House.

Austin, Regina. 1988. Employer Abuse, Worker Resistance, and the Tort of Intentional Infliction of Emotional Distress. Stanford Law Review 41:1-59.

Cotterrell, Roger ed. 1994. Law and Society. New York: New York University Press.

De Certeau, Michel. 1984. The Practice of Everyday Life, trans. Steven Rendall. Berkeley and Los Angeles: University of California Press.

Ellickson, Robert C. 1986. Of Coase and Cattle: Dispute Resolution Among Neighbors in Shasta County. Stanford Law Review 38:623-87.

Feldman, Heidi Li. Forthcoming. Care, Character, and American Tort Law. New York: Routledge.

Fisher, William W. III, Morton J. Horwitz, and Thomas A. Reed, eds. 1993. American Legal Realism. Oxford, England: Oxford University Press.

Foucault, Michel. 1980a. Power/Knowledge: Selected Interviews and Other Writings 1972-1977, ed. Colin Gordon; trans. Colin Gordon et al. New York: Pantheon Books.

1980b. The History of Sexuality. Vol. 1, An Introduction, trans. Robert Hurley. New York: Vintage Books.

- 1982. Afterword: The Subject and Power. In Michel Foucault: Beyond Structuralism and Hermeneutics, ed. Hubert L. Dreyfus and Paul Rabinow. Chicago: University of Chicago Press.

Friedman, Lawrence M. 1986. The Law and Sociery Movement. Stanford Law Review 38:763-80.

Gabel, Peter. 1984. The Phenomenology of Rights-Consciousness and the Pact of the Withdrawn Selves. Texas Law Review 62:1563-98.

Garth, Bryant, and Joyce Sterling. 1998. From Legal Realism to Law and Society: Reshaping Law for the Last Stages of the Social Activist State. Law and Society Review 32:409-71.

Gordon, Robert W. 1994. The Elusive Transformation. Yale Joumal of Law and the Humanities 6:137-62.

Grey, Thomas. 1983. Langdell's Orthodoxy. University of Pittsburgh Law Review 45:1-53.

Halley, Janet E. 1994. Sexual Orientation and the Politics of Biology: A Critique of the Argument from Immutability. Stanford Law Review 46:503-68.

Hunt, Alan. 1992. Foucault's Expulsion of Law: Toward a Retrieval. Law and Social Inquiry 17:1-38.

Kairys, David, ed. 1990. The Politics of Law: A Progressive Critique. New York: Pantheon Books.

Kelman, Mark. 1987. A Guide to Critical Legal Studies. Cambridge, Mass.: Harvard University Press.

Kennedy, Duncan. 1993. Sexy Dressing Etc.: Essays on Power and Politics of Cultural Identity. Cambridge, Mass.: Harvard University Press. 
Levine, Felice J. 1990a. Goose Bumps and "The Search for Intelligent Life" in SocioLegal Studies: After Twenty-Five Years. Law and Society Review 24:7-33.

- 1990b. "His" and "Her" Story: The Life and Future of the Law and Society Movement. Florida State University Law Review 18:69-90.

Llewellyn, Karl N. 1931. Some Realism about Realism-Responding to Dean Pound. Harvard Law Review 44:1222-64.

Lyotard, Jean-Francois. 1989. The Postmodem Condition: A Report on Knowledge, trans. Geoff Bennington and Brian Massumi. Minneapolis: University of Minnesota Press.

McCann, Michael W., and Tracey March. 1995. Law and Everyday Forms of Resistance: A Socio-Political Assessment. In Studies in Law, Politics, and Society, ed. Austin Sarat and Susan S. Silbey. Greenwich, Conn.: JAI Press.

Merry, Sally Engle. 1990. Getting Justice and Getting Even: Legal Consciousness Among Working-Class Americans. Chicago: University of Chicago Press.

Munger, Frank. 1998. Mapping Law and Society. In Sarat et al. 1998.

Note. 1982. 'Round and 'Round the Bramble Bush: From Legal Realism to Critical Legal Scholarship. Harvard Law Review 95:1669-90.

Sarat, Austin. 1990. ". . . The Law Is All Over": Power, Resistance and the Legal Consciousness of the Welfare Poor. Yale Journal of Law and the Humanities 2:343-79.

Sarat, Austin, Marianne Constable, David Engel, Valerie Hans, and Susan Lawrence, eds. 1998. Crossing Boundaries: Traditions and Transformations in Law and Society Research. Evanston, Ill: Northwestern University Press.

Sarat, Austin, and Thomas R. Kearns, eds. 1993. Law in Everyday Life. Ann Arbor: University of Michigan Press.

Sarat, Austin, and Susan Silbey. 1988. The Pull of the Policy Audience. Law and Policy 10:97-166.

Sewell, William H. 1992. A Theory of Structure: Duality, Agency, and Transformation. American Journal of Sociology 98:1-29.

Silbey, Susan S. 1989. A Sociological Interpretation of the Relationship between Law and Society. In Law and the Ordering of Our Life Together, ed. Richard John Neuhaus. Grand Rapids, Mich.: William B. Eerdmans.

. 1992. Making a Place for a Cultural Analysis of Law. Law E⿱ Social Inquiry $17: 39-48$.

Silbey, Susan S., and Austin Sarat. 1987. Critical Traditions in Law and Society Research. Law and Society Review 21:165-74.

Simon, Jonathan. 1999. Law After Society. Law and Social Inquiry 24:143-94.

Sperber, Dan. 1996. Explaining Culture: A Naturalistic Approach. Oxford, England: Blackwell Publishers.

Trubek, David M. 1990. Back to the Future: The Short, Happy Life of the Law and Society Movement. Florida State University Law Review 18:1-55.

Trubek, David M., and John Esser. 1989. "Critical Empiricism" in American Legal Studies: Paradox, Program, or Pandora's Box? Law and Social Inquiry 14:3-52.

Tushnet, Mark. 1980. Post-Realist Legal Scholarship. Wisconsin Law Review 1980:1383-1401.

- 1998. "Everything Old Is New Again": Early Reflections on the "New Chicago School." Wisconsin Law Review 1998:579-90.

West, Robin L. 1987. The Difference in Women's Hedonic Lives: A Phenomenological Critique of Feminist Legal Theory. Wisconsin Women's Law Joumal 3:81-145.

Wilbur, Richard. 1988. New and Collected Poems. New York: Harcourt Brace Jovanovich. Yngvesson, Barbara. 1993. Virtuous Citizens, Disruptive Subjects: Order and Complaint in a New England Court. New York: Routledge. 
*⿻三丨 